\title{
Understanding the effects of constructivist learning environments: introducing a multi-directional approach
}

\author{
Sofie M. M. Loyens · David Gijbels
}

Published online: 19 August 2008

(C) The Author(s) 2008. This article is published with open access at Springerlink.com

The idea to organize a special issue on the effects of constructivist learning environments originated at the 2007 annual meeting of the American Educational Research Association in Chicago. We organized a symposium on this topic, which was attended by a large audience and received many positive reactions. Therefore, we came up with the plan to translate our symposium into a special issue. In addition to the papers that were presented in the symposium, we invited several other experts in the field to contribute to this special issue. We are pleased to present the results of that collaborative effort.

The title of this special issue, "Effects of constructivist learning environments," might raise questions for the reader. What is a constructivist learning environment and what effects are intended? In this introduction, we deal with these questions. We present a working definition of constructivism, discuss elements of constructivist learning environments, and explain the connotation of new learning environments (NLEs) used herein. Further, we discuss the context in which earlier research on effects of constructivist learning environments took place and we argue that more than cognitive effects should be considered in this respect. Finally, we give an introduction on the papers that are part of this special issue.

\section{Constructivism and constructivist learning environments}

The way in which people try to make sense of situations or, in other words, how people create meaning, is the main concern of constructivist theories. A clear, unequivocal definition of constructivism is, however, hard to find (Gijbels et al. 2006; Loyens 2007). Although this concept is currently influential in psychology and education, it is defined and embodied in varied ways (e.g., Phillips 2000). Different perspectives of constructivism

\footnotetext{
S. M. M. Loyens ( ()

Department of Psychology, T13-44, Erasmus University Rotterdam, Burg. Oudlaan 50, 3062 PA

Rotterdam, The Netherlands

e-mail: Loyens@fsw.eur.nl

D. Gijbels

Institute for Education and Information Sciences, University of Antwerp, Antwerp, Belgium
} 
emphasize either individual cognitive processes, such as cognitive constructivism that is concerned with the knowledge construction of the individual, or social co-constructions of knowledge, such as social constructivism that stress the collaborative processes in knowledge building (Windschitl 2002). However, the many faces of constructivism are many faces of the same head. In essence, constructivism is a view of learning that considers the learner as a responsible, active agent in his/her knowledge acquisition process (Loyens 2007). In other words, the numerous perspectives on constructivism could be grouped around a fundamental assumption about learning: Knowledge is actively constructed by the learner (Birenbaum 2003; Harris and Alexander 1998; Tynjälä 1999).

The constructivist learning environment, however, is difficult to characterize and the constitution of the instructional principles of constructivist theory, which guide matters of the nature and quality of educational materials and the learning environment, often remains unclear (Harris and Alexander 1998; Tenenbaum et al. 2001). Despite many animated discussions, there seems to be no incompatibility among the different existing theories and integrative approaches seem to be developing (Resnick 1994; Tynjälä 1999; Vosniadou 1996). As such, constructivist theories have led to several applications in educational practice, such as problem-based learning (PBL). In general, constructivist learning environments contain several features that are believed to promote effective learning, which will be discussed subsequently.

As mentioned, the essence of constructivism is that students actively construct knowledge. In other words, the acquisition of knowledge is a process of knowledge construction (Cunningham 1992). The core element of this assumption is that learners interpret new information using knowledge that they have already acquired. Learners activate prior knowledge and try to relate new information to knowledge they already possess. By doing so, understanding subject matter is a function of knowledge construction and transformation, not merely information acquisition and accumulation (Blumenfeld 1992). Wheatley refers to this process with the following quote: "Knowledge is always someone's knowledge" (Wheatley 1991, p. 13). In addition, learning that builds on what students already know leads to an increase in not only retention, but in interest and motivation as well (Forbes et al. 2001).

The importance of cooperative learning is a second assumption put forward by constructivist theorists (Loyens et al. 2007). Social interactions with fellow students, teachers, and others contribute to the construction of knowledge (Steffe and Gale 1995). It should be noted here that constructivists have different opinions concerning the influence of cooperation on knowledge acquisition. However, in general it is believed that social negotiation and interaction are crucial elements in acquiring knowledge (Greeno et al. 1996). Social interactions among students can also facilitate communication of ideas about subject matter, because their level of understanding is more similar to each other as compared to the teacher's level (Slavin 1996). In addition, cooperative learning enables student discussions that are indicative for students of their level of prior knowledge. These discussions provide students with both the direction and extent of study that needs to be undertaken to acquire a deep understanding of the subject matter to be studied.

Using one's metacognitive skills to set academic learning goals or, put differently, be a self-regulated learner (Paris and Paris 2001; Zimmerman 1989) is another element that is often considered in constructivist theories (Loyens et al. 2007). Self-regulation is an umbrella term for various aspects such as goal setting, self-observation, self-assessment, and self-reinforcement, all of which are believed to influence learning. Although all learners are inevitably engaged in some form of self-regulation (i.e., they all plan, monitor, and evaluate their behavior to some degree, Winne 1995), effective self-regulation requires 
having goals and the motivation to attain them. To be able to regulate your own learning is viewed as the key to successful learning in school and beyond (Boekaerts 1999). Studies on self-regulation have demonstrated that effective learners possess and use a substantial knowledge base about learning that allows them to organise, plan, and monitor most aspects of learning tasks in a task-appropriate way (Cantwell and Moore 1996). Further, programs that promote self-regulated learning have been found to be beneficial for students' achievement (e.g., Mason 2004).

Finally, most constructivists agree on the assumption that learning situations preferably have to resemble real-life or authentic situations. A way to accomplish this is by confronting students with complex, ill-structured problems; similar to the kinds of problems they will face in their future profession. These problems serve as a challenge to students' reasoning or problem-solving skills and as an organizer for their learning (Voss and Post 1988; White and Frederiksen 1998). Complex problems refer to problems that have many interacting elements and that can lead to multiple solutions; they are not simply difficult problems. By solving problems, learners develop understanding of subject matter. They apply and represent their ideas in a manner similar to the way in which experienced individuals in the field generate and use knowledge (Blumenfeld 1992). This aspect of constructivist views is consistent with the notion of learning in a context.

\section{Constructivism and new learning environments}

Generally, the theory of constructivism is frequently referred to when discussing so called new learning environments. The term new learning was introduced in 2000 by Simons, van der Linden, and Duffy to refer to "new learning outcomes, new kinds of learning processes and new instructional models that are both wanted by society and stressed in educational and psychological theory" (Simons et al. 2000, p. 1). Since then, the term new learning environments has been used to refer to learning environments that intend to develop an educational setting to meet the challenge for today's higher education, making the students' learning the core issue and defining instruction as enhancing the learning process (e.g., Gijbels et al. 2006). These new learning environments are mainly (but not exclusively) rooted in constructivist theory and claim to have the potential to improve the educational outcomes for students in higher education (Lea et al. 2003).

\section{Research on the effects of constructivist learning environments}

Constructivist theories have been subject to many debates and it is clear that not everyone embraces a constructivist view of learning. Some educators believe that the teacher, and not the learner, should be in charge of students' learning process; s/he should direct and control. These educators also believe that constructivists often do not focus sufficiently on basic academic tasks, whereas too much emphasis is laid on skills (Santrock 2001). Others have even argued that constructivism is in conflict with human, cognitive architecture (Kirschner et al. 2006). However, these discussions are mainly problematic because the starting points are extremes, sometimes even caricatures of traditional teaching (cognitivism) and constructivism, which are presented as inherently incompatible. Focusing on extreme views makes that one inevitably faces the shortcomings of either view, which sets in a movement to the other extreme (Elshout 2000). 
It became clear from these discussions that there appears to be a gap between educational practice and the theory of constructivism and that the different theoretical positions of constructivism, all with varying emphasis, have made it difficult to narrow the bridge between theory and practice (De Corte 2000; Kennedy 1997). This gap poses one of the challenges to the constructivist reaction to traditional teaching (Harris and Alexander 1998). Investigating the effects of constructivist learning environments seems to be a step in the good direction: What happens in constructivist learning environments and does it work?

Previous research has demonstrated that empirical studies regarding the effects of constructivist learning environments do not always show the expected learning outcomes (e.g., Segers 1996). Possible explanations have been proposed to explain why these learning environments do not always appear to fulfill their promise (Delva et al. 2000). It has been argued that effect studies do not have to exclusively focus on curriculum features, solely examining if instructional goals have been met and mainly focusing on "cognitive" effects such as students' performance. Instead, research should take stock of a broader range of variables influencing the learning process (Loyens et al. 2006). In other words, understanding and improving educational effects demands a multi-directional approach (Goodyear and Hativa 2002). This multi-directional approach to better understand the effects of constructivist learning environments is the focus of this special issue.

The authors represented in this special issue come from different backgrounds implying that their views on constructivist learning environments differ. This affected the way they gave shape to their contributions. The influence of constructivist learning environments on aspects of learning besides or on top of achievement will be taken into account. More specifically, factors such as approaches to learning, perceptions of assessment demands, assessment preferences, conceptions of learning, personal and role interest, self-regulated strategy development, regulation and processing strategies, and differences in how students use resources in computer supported collaborative learning environments will be discussed in this issue.

\section{Overview of the studies}

In general, the studies of this special issue can be divided in two categories. One category discusses articles focusing on the effects of specific "constructivist interventions" (i.e., articles by Baeten, Dochy, \& Struyven; Dinsmore, Alexander, \& Loughlin; Harris, Santangelo, \& Graham, and Hmelo-Silver, Chernobilsky, \& Jordan). Articles of the second category (i.e., Gijbels, Segers, \& Struyf and Loyens, Rikers, \& Schmidt) approach constructivist learning environments from a student-perspective, stressing students' perceptions of assessment demands and students' conceptions of constructivist learning, respectively.

The study of Baeten et al. focuses on the relations between experiences with portfolio assessment in a course that was designed based on constructivist principles, students' approaches to learning their assessment preferences. The findings indicate that students' preferences for student participation in examination and for permanent evaluation decreased significantly. Further, the researchers found that students decreased their deep approaches to learning and increased their surface approaches to learning although the surface approach to learning proved to be a significant but negative predictor for the portfolio assessment score. 
Dinsmore and colleagues scrutinized the effects of students' participation in a collaborative, project-based engineering design course on their domain knowledge, interests, and strategic processing. Significant effects were found for students' declarative knowledge, but not for students' procedural or principled knowledge, nor for students' personal interest in the domain of engineering. They conclude that a due consideration of the content under study as well as learner characteristics is pivotal.

In their review article, Harris et al. plead for an integration of multiple theoretical perspectives in order to develop powerful approaches to learning. Advocates of constructivist learning environments should look further than the constructivist theoretical perspective, since effective instruction should incorporate the best of all theoretical worlds in education. These authors support their claim with studies on self-regulated strategy development in the area of writing.

The study of Hmelo-Silver et al. investigated how collaborative knowledge building unfolds and how these processes are mediated. They use Chronologically-ordered Representations of Discourse and Tool-Related Activity (CORDTRA) diagrams in order to demonstrate how visually representing the chronology of tool use and discourse in an activity can enhance analysis of collaborative learning in a computer supported learning environment. Their analyses suggest that an important locus of differences is how students use resources and engage in different kinds of metacognitive talk and knowledge transforming activities, sometimes to the group's detriment.

The article of Gijbels and colleagues looked into the influence of a constructivist learning environment on students' perceptions of assessments demands and students' approaches to learning. Further, the researchers examined how changes in approaches to learning relate to changes in assessment demands. Results demonstrated that a course designed according to constructivist principles led to more deep-level assessment demands. However, this change in perceptions did not influence students' approaches to learning, since students reported more frequent use of surface approaches to learning during the course. The authors conclude that students' initial approaches to learning at the beginning of the course are more determinative for the change in those approaches compared to students' perceptions of assessment demands.

Finally, the study of Loyens and colleagues also starts from a student perspective. They examined how students' beliefs and ideas (i.e., conceptions) about constructivist learning have an effect on their actual study behavior in terms of regulation and processing strategies. The authors conclude that structural relations exist between conceptions of constructivist learning and regulation and processing strategies. Their study also indicates that students who express doubt with regard to their own learning capacities seem to be at risk for adopting an inadequate regulation strategy.

To avoid the reasonable suspicion that two editors who put together a special issue on such a highly debated theme might have an intransigent viewpoint of their own that colors the volume, authors from a different angle were invited to present their considered opinions about the papers in this special issue. In their commentary, it will become clear that sometimes their opinions concur with those of the contributors, but sometimes they do not.

Acknowledgements We would like to thank the following people who were a great help in organizing this special issue: Peter Goodyear, Sonia Bartoluzzi, and Ton de Jong. Furthermore, we gratefully acknowledge all contributors to this special issue. Finally, last but not least, we would like to thank all reviewers for their helpful comments: Laura Helle, Päivi Tynjälä, Diana Dolmans, Mien Segers, Tamara van Gog, Fred Paas, Katrien Struyven, Andy Elby, Remy Rikers, Dan Hickey, Silvia Mamede, Paul Wimmers, Mark Newman, Jan-Willem Strijbos, Pieter-Jelle Beers, Karen Harris, Sari Lindblom-Ylänne, and Patricia Alexander. Both authors contributed equally to this article. 
Open Access This article is distributed under the terms of the Creative Commons Attribution Noncommercial License which permits any noncommercial use, distribution, and reproduction in any medium, provided the original author(s) and source are credited.

\section{References}

Birenbaum, M. (2003). New insights into learning and teaching and their implications for assessment. In M. Segers, F. Dochy \& E. Cascallar (Eds.), Optimising new modes of assessment: In search for qualities and standards (pp. 13-36). Dordrecht, the Netherlands: Kluwer Academic Publishers.

Blumenfeld, P. C. (1992). Classroom learning and motivation: Clarifying and expanding goal theory. Journal of Educational Psychology, 84, 272-281.

Boekaerts, M. (1999). Self-regulated learning: Where we are today. International Journal of Educational Research, 31, 445-457.

Cantwell, R. H., \& Moore, P. J. (1996). The development of measures of individual differences in selfregulatory control and their relationship to academic performance. Contemporary Educational Psychology, 21, 500-517.

Cunningham, D. J. (1992). Beyond educational psychology: Steps toward an educational semiotic. Educational Psychology Review, 4, 165-194.

De Corte, E. (2000). Marrying theory building and the improvement of school practice: a permanent challenge for instructional psychology. Learning and Instruction, 10, 249-266.

Delva, M. D., Woodhouse, R. A., Hains, S., Birtwhistle, R. V., Knapper, C., \& Kirby, J. R. (2000). Does PBL matter? Relations between instructional context, learning strategies, and learning outcomes. Advances in Health Sciences Education, 5, 167-177.

Elshout, J. J. (2000). Constructivisme (?) en cognitieve psychologie. Pedagogische Studiën, 77, 134-138.

Forbes, H., Duke, M., \& Prosser, M. (2001). Students' perceptions of learning outcomes from group-based, problem-based teaching and learning activities. Advances in Health Sciences Education, 6, 205-217.

Gijbels, D., van de Watering, G., Dochy, F., \& van den Bossche, P. (2006). New learning environments and constructivism: The students' perspective. Instructional Science, 34, 213-226.

Goodyear, P., \& Hativa, N. (2002). Introduction: Research on teacher thinking, beliefs and knowledge in higher education. In N. Hativa \& P. Goodyear (Eds.), Teacher thinking, beliefs and knowledge in higher education (pp. 1-13). Dordrecht, the Netherlands: Kluwer academic publishers.

Greeno, J. G., Collins, A. M., \& Resnick, L. B. (1996). Cognition and learning. In D. C. Berliner \& R. C. Calfee (Eds.), Handbook of educational psychology (pp. 15-46). New York: Simon \& Schuster Macmillan.

Harris, K. R., \& Alexander, P. A. (1998). Integrated, constructivist education: Challenge and reality. Educational Psychology Review, 10, 115-127.

Kennedy, M. M. (1997). The connection between research and practice. Educational Researcher, 26, 4-12.

Kirschner, P. A., Sweller, J., \& Clark, R. E. (2006). Why minimal guidance during instruction does not work: An analysis of the failure of constructivist, discovery, problem-based, experiential, and inquirybased teaching. Educational Psychologist, 41, 75-86.

Lea, S. J., Stephenson, D., \& Troy, J. (2003). Higher education students' attitudes toward student-centred learning: Beyond 'educational bulimia'? Studies in Higher Education, 28, 321-334.

Loyens, S. M. M. (2007). Students' conceptions of constructivist learning. Doctoral dissertation. Rotterdam, the Netherlands: Optima Grafische Communicatie.

Loyens, S. M. M., Rikers, R. M. J. P., \& Schmidt, H. G. (2007). Students' conceptions of distinct constructivist assumptions. European Journal of Psychology of Education, 12, 179-199.

Loyens, S. M. M., Rikers, R. M. J. P., \& Schmidt, H. G. (2006). Students' conceptions of constructivist learning: A comparison between a traditional and a problem-based learning curriculum. Advances in Health Sciences Education, 11, 365-379.

Mason, L. H. (2004). Explicit self-regulated strategy development versus reciprocal questioning: Effects on expository reading comprehension among struggling readers. Journal of Educational Psychology, 96, 283-296.

Paris, S. G., \& Paris, A. H. (2001). Classroom applications of research on self-regulated learning. Educational Psychologist, 36, 89-101.

Phillips, D. C. (Ed.). (2000). Constructivism in education. Opinions and second opinions on controversial issues. Chicago: The University Press of Chicago. 
Resnick, L. B. (1994). Situated rationalism: Biological and social preparation for learning. In L. A. Hirschfeld \& S. A. Gelman (Eds.), Mapping the mind (pp. 474-494). New York: Cambridge University Press.

Santrock, J. W. (2001). Educational psychology. New York: McGraw-Hill.

Segers, M. (1996). Assessment in a problem-based economics curriculum. In M. Birenbaum \& F. Dochy (Eds.), Alternatives in assessment of achievements, learning processes and prior learning (pp. 201226). Boston: Kluwer Academic Press.

Simons, R. J., van der Linden, J., \& Duffy, T. (2000). New learning: Three ways to learn in a new balance. In R. J. Simons, J. van der Linden \& T. Duffy (Eds.), New learning (pp. 1-20). Dordrecht: Kluwer Academic Publishers.

Slavin, R. E. (1996). Research on cooperative learning and achievement: What we know, what we need to know. Contemporary Educational Psychology, 21, 43-69.

Steffe, L. P., \& Gale, J. (1995). Constructivism in education. Hillsdale, NJ: Lawrence Erlbaum Associates.

Tenenbaum, G., Naidu, S., Jegede, O., \& Austin, J. (2001). Constructivist pedagogy in conventional oncampus and distance learning practice: An exploratory investigation. Learning and Instruction, 11, 87-111.

Tynjälä, P. (1999). Towards expert knowledge? A comparison between a constructivist and a traditional learning environment in the University. International Journal of Educational Research, 33, 355-442.

Vosniadou, S. (1996). Towards a revised cognitive psychology for new advances in learning and instruction. Learning and Instruction, 6, 95-109.

Voss, J. F., \& Post, T. A. (1988). On the solving of ill-structured problems. In M. T. H. Chi, R. Glaser \& M. J. Farr (Eds.), The nature of expertise (pp. 261-285). Hillsdale, NJ: Lawrence Erlbaum.

Wheatley, G. H. (1991). Constructivist perspectives on science and mathematics learning. Science Education, 75, 9-21.

White, B. Y., \& Frederiksen, J. R. (1998). Inquiry, modeling, and metacognition: Making science accessible to all students. Cognition and Instruction, 16, 3-18.

Windschitl, M. (2002). Framing constructivism in practice as the negotiation of dilemmas: An analysis of the conceptual, pedagogical, cultural, and political challenges facing teachers. Review of Educational Research, 72, 131-175.

Winne, P. H. (1995). Self-regulation is ubiquitous but its forms vary with knowledge. Educational Psychologist, 30, 217-221.

Zimmerman, B. J. (1989). A social cognitive view of self-regulated academic learning. Journal of Educational Psychology, 81, 329-339. 